\title{
Timotein kasvustorakenteen säätely, sadon muodostus ja kylmänkestävyys
}

\author{
Venla Jokela ${ }^{1}$, Juha Luhtanen ${ }^{1}$, Mika Isolahti ${ }^{2}$, Perttu Virkajärvi ${ }^{3}$ ja Mervi Seppänen ${ }^{1}$ \\ ${ }^{1}$ Maataloustieteiden laitos, Latokartanonkaari 5, 00014 Helsingin yliopisto, etunimi.sukunimi@ helsinki.fi \\ ${ }^{2}$ Boreal Kasvinjalostus Oy, 31600 Jokioinen, etunimi.sukunimi@boreal.fi \\ ${ }^{3}$ MTT Kotieläintuotannon tutkimus, Halolantie 31 A, 71750 Maaninka, etunimi.sukunimi@mtt.fi
}

\section{Tiivistelmä}

Timotei (Phleum pratense L.) on tärkein Suomessa viljelty nurmirehukasvi erityisesti sen hyvän talvenkestävyyden ja sadon laadun takia. Kasvusto muodostuu kolmesta versotyypistä: vegetatiivisista, elongoituvista ja kukkivista versoista. Elongoituva verso on timoteille ominainen versotyyppi, jonka verson pituuskasvu on alkanut, mutta verson kärkikasvupisteen kehitys on pysähtynyt vegetatiiviseen vaiheeseen. Ensimmäisessä sadossa kukkivat versot muodostavat pääosan sadosta, kun taas toinen sato koostuu enimmäkseen vegetatiivisista ja elongoituvista versoista. Elongoituvilla versoilla on suuri merkitys sadontuoton kannalta erityisesti toisessa korjuussa ja lisäksi niiden sulavuus voi olla kukkivia versoja parempi. Timotei on pitkän päivän kasvi, joka kukkii, kun kukkimisille kriittinen päivän pituus ylittyy. Se ei vaadi kukkiakseen vernalisaatiota eli kylmäkäsittelyä, ja tämän vuoksi kukkivia versoja voidaan havaita myös toisessa sadossa, joka ei ole kokenut talvea. Kukintaa, ja luultavasti myös elongoituvien versojen muodostumista, säädellään ympäristötekijöiden sekä kasvin endogeenisien tekijöiden, kuten vernalisaation, gibberelliinihapon (GA), päivän pituuden ja kasvin koon, iän ja energiatalouden, kautta. Tässä tutkimuksessa selvitimme, miten erilaiset kukintasignaalit, erityisesti vernalisaatio, päivänpituus ja GA, vaikuttavat timotein kasvuston rakenteeseen ja sadon muodostumiseen sekä kuinka kaksi kukkimisen indusoijageeniä ilmenee erilaisissa olosuhteissa.

Kasvihuonekokeessa tutkittiin kahden timoteigenotyypin vasteita vernalisaatiolle $(0,2,10$, 12,18 tai 20 viikkoa), päivän pituudelle (12 tai 16 tuntia) ja gibberelliinille $\left(\mathrm{GA}_{3}\right)$. Käsittelyiden jälkeen laskettiin elongoituvien ja kukkivien versojen lukumäärät kerran viikossa. Vernalisaatiolla oli vaikutusta eri versotyyppien muodostumiseen. Elongoituvien versojen määrä oli korkeampi sekä vernalisoiduissa että ei-vernalisoiduissa kasveissa. Lyhyessä $(12 \mathrm{~h})$ päivän pituudessa ei muodostunut ollenkaan kukkivia tai elongoituvia versoja. Pitkässä päivässä $(16 \mathrm{~h})$ vernalisaatio lisäsi kukkivien versojen muodostumista, kun taas ei-vernalisoituihin kasveihin kehittyi enemmän elongoituvia versoja. $\mathrm{GA}_{3}$-käsittely ei pystynyt korvaamaan pitkän päivän tarvetta kukkivien tai elongoituvien versojen muodostumiselle lyhyessä päivän pituudessa. VRN1 ja VRN3 geenien ekspressioanalyyseissa havaittiin ilmenemisen ja genotyypin kasvutavan välillä yhtäläisyyksiä. Tulosten perusteella pohditaan versojen kehittymisen säätelyn vaikutusta timotein sadonmuodostukseen ja kuinka alkuperältään erilaiset genotyypit eroavat versojen muodostuksessa.

Asiasanat: gibberelliinihappo, kukkiminen, päivänpituus, timotei, vernalisaatio, versotyypit, VRN1, VRN3 


\section{Johdanto}

Timotei (Phleum pratense L.) on tärkein Suomessa viljelty nurmirehukasvi erityisesti sen hyvän talvenkestävyyden ja sadon laadun takia. Sen kasvusto muodostuu kolmesta versotyypistä: vegetatiivisesta, elongoituvasta ja kukkivasta versosta. Elongoituva verso on merkittävistä nurmikasveista ainoastaan timoteille ominainen versotyyppi, jonka verson pituuskasvu on alkanut, mutta verson kärkikasvupisteen kehitys on pysähtynyt vegetatiiviseen vaiheeseen Ensimmäisessä sadossa kukkivat versot muodostavat pääosan sadosta, kun taas toinen sato koostuu enimmäkseen vegetatiivisista ja elongoituvista versoista (Virkajärvi ym. 2011). Elongoituvilla versoilla on suuri merkitys sadontuoton kannalta erityisesti toisessa korjuussa ja lisäksi niiden sulavuus voi olla kukkivia versoja parempi.

Kukintaa, ja luultavasti myös elongoituvien versojen muodostumista, säädellään ympäristötekijöiden sekä kasvin endogeenisien tekijöiden, kuten vernalisaation, gibberelliinihapon (GA), päivän pituuden ja kasvin koon, iän ja energiatalouden, kautta. (Srikanth \& Schmid 2011). Nurmikasvit voidaan luokitella vernalisaatio- ja päivänpituusvaatimuksensa perusteella primaari-induktion (vernalisaatio), kaksoisinduktion (vernalisaatio ja pitkä päivä) tai ainoastaan pitkän päivän vaativiin kasveihin (Heide 1994). Timotei on pitkän päivän kasvi, joka kukkii, kun kukkimisille kriittinen päivän pituus ylittyy. Timotei ei vaadi kukkiakseen vernalisaatiota eli kylmäkäsittelyä, ja tämän vuoksi kukkivia versoja voidaan havaita myös toisessa sadossa, joka ei ole kokenut talvea. Vernalisaation on kuitenkin havaittu nopeuttavan ja edistävän timotein kukintaa (Seppänen ym. 2010) ja hiljattain on löydetty myös timoteigenotyyppi, jolla on vernalisaatiovaatimus kukkimiselle (Fiil ym. 2011). Timotein genotyypit voidaan jaotella eteläisiin ja pohjoisiin lajikkeisiin, jotka eroavat $\mathrm{mm}$. kasvutavaltaan, kehitysrytmiltään ja kylmänkestävyydeltään toisistaan. Eteläiset genotyypit ovat kasvurytmiltään nopeampia, mikä ilmenee mm. hyvänä jälleenkasvukykynä, kun taas pohjoisten genotyyppien etuna on niiden parempi talvenkestävyys (Isolahti 2010).

Syysvehnällä ja - ohralla VRN1 geenin ekspressio lisääntyy kasvin siirtyessä vegetatiivisesta kasvusta kukintavaiheeseen (Danyluk ym. 2003). Seppänen ym. (2010) havaitsivat $V R N 1: n$ ilmenemisen lisääntyvän timoteilla 10 viikon vernalisaatiokäsittelyn jälkeen ja ajoittuvan aikaan, jolloin kärkikasvupiste siirtyy vegetatiivisesta generatiiviseen vaiheeseen. VRN3:n rooli syysvehnällä liittyy myös kukinnan indusoimiseen siten, että se yhdistää vernalisaatio- ja päivänpituusreittien signaaleja (Li ym. 2011).

Tässä tutkimuksessa selvitimme, kuinka erilaiset kukintasignaalit, erityisesti vernalisaatio, päivänpituus ja GA, vaikuttavat timotein kasvuston rakenteeseen ja sadon muodostumiseen sekä kuinka kaksi kukkimisen indusoijageeniä ilmenee erilaisissa olosuhteissa alkuperältään erilaisissa timoteigenotyypeissä.

\section{Aineisto ja menetelmät}

Kasvihuonekoe koostui kahdesta erillisestä kokeesta, joissa tutkittiin siemenmateriaalilla kahden timoteilajikkeen (Iki ja Tuure) vasteita a) vernalisaatiolle $(0,2,10,12,18$ tai 20 viikkoa) tai b) vernalisaatiolle ( 0 tai 10 viikkoa), päivän pituudelle (12 tai 16 tuntia) ja gibberelliinille $\left(\mathrm{GA}_{3}\right)$. Lisäksi klooniaineistolla selvitettiin vernalisaation (0-15 viikkoa) vaikutusta kasvuston rakenteeseen eteläisellä ja pohjoisella genotyypillä. Timotein siementaimia kasvatettiin kasvihuoneella $\left(20{ }^{\circ} \mathrm{C}, 12\right.$ tunnin päivänpituus) kaksi viikkoa ennen siirtoa kasvatuskaappeihin (Weiss Technik, Saksa) joko a) 2-20 viikoksi tai b) 10 viikoksi vernalisaatiokäsittelyyn $\left(6{ }^{\circ} \mathrm{C} / 4{ }^{\circ} \mathrm{C}\right.$, päivä/yö, 8 tunnin päivänpituus). Vernalisaation jälkeen kasvit siirrettiin a) 16 tunnin päivänpituuteen tai b) joko 12 tai 16 tunnin päivänpituuteen ja käsiteltiin gibberelliinihapolla tai kontrollikäsittelyllä. Gibberelliinihappoa $\left(\mathrm{GA}_{3}\right)$ pipetoitiin ylimmän lehtitupen sisään $25 \mu \mathrm{g} 10 \mu \mathrm{l}$ :ssa $20 \%$ etanolia (mukaillen MacMillan ym. 2005). Kontrollikasvit käsiteltiin $20 \%$ etanolilla.

Kasveista havainnoitiin ennen kylmäkäsittelyä ja kolme kertaa kylmäkäsittelyn jälkeen kasvin pääverson pituus sekä lehtien ja versojen lukumäärä. Elongoituvien ja kukkivien versojen 
kehittymistä seurattiin viikoittain koko kokeen ajan. Elongoituva verso luokiteltiin versoksi, jossa oli aitokorsi ja vähintään kaksi solmua. Kasveista kerättiin näytteitä DNA- ja RNA-analyyseja varten 0,7 ja 14 vuorokautta vernalisaation jälkeen. Näytteenoton yhteydessä kasvien kärkikasvupisteen kehitysaste määritettiin Sweet ym. (1991) mukaan.

Ekspressioanalyysissa selvitettiin eri käsittelyjen vaikutusta VRN1 ja VRN3 geenien ilmenemiseen. Timoteille suunniteltiin lajispesifit alukkeet käyttäen sekvenssidataa vehnän VRN1 geenistä (Seppänen ym. 2010). VRN3 aluketiedot saatiin valmiina Tanskasta J. Andersenin laboratoriosta. Ekspressioanalyysi suoritettiin kvantitatiivisella RT-PCR laitteella (Roche Light cycler 480, Indianapolis, USA).

\section{Tulokset ja tulosten tarkastelu}

Vernalisaatiolla oli vaikutusta eri versotyyppien muodostumiseen. Elongoituvien versojen määrä oli korkeampi kaikissa kasveissa lukuun ottamatta 18 ja 20 viikkoa vernalisoituja 'Iki' lajikkeen kasveja (kuva 1). Pitkässä päivässä (16 h) vernalisaatio lisäsi kukkivien versojen muodostumista, kun taas eivernalisoituihin kasveihin kehittyi enemmän elongoituvia versoja. Vernalisaatiolla oli aina negatiivinen vaikutus elongoituvien versojen määrään. 12 viikon vernalisaation jälkeen kukkivien versojen määrä kasvoi molemmilla genotyypeillä verrattuna lyhyemmän aikaa vernalisoituihin kasveihin. Seppänen ym. (2010) havaitsivat, että kukkivien versojen määrä kasvaa 10 viikkoa vernalisoiduissa kasveissa ja kasvuvaihe siirtyy vegetatiivisesta kasvusta generatiiviseen kasvuun. Genotyypeillä ei ollut merkitsevää eroa versojen määrissä.

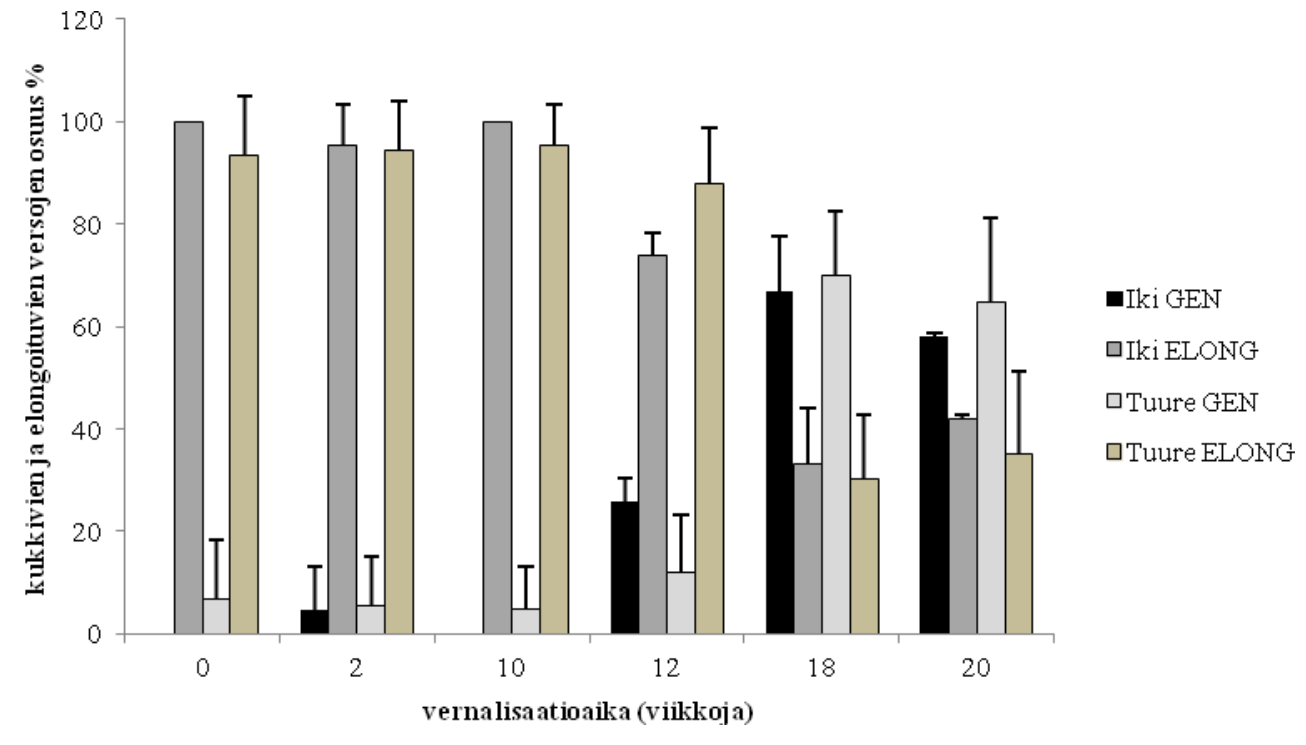

Kuva 1. Elongoituvien ja kukkivien versojen \%-osuus 0- 20 viikkoa vernalisoiduissa lajikkeissa 'Iki' ja 'Tuure' kahdeksan viikon kasvatuksen jälkeen 16 tunnin päivänpituudessa. $n=9 \pm$ SE.

Tutkittaessa eroja eteläistä ja pohjoista alkuperää olevien genotyyppien versojen lukumäärissä havaittiin, että pohjoinen genotyyppi tuotti enemmän elongoituvia versoja, kun taas eteläinen tuotti kukkivia versoja (Kuvat 2a ja b). Eteläinen genotyyppi ei vaatinut vernalisaatiota kukkiakseen, vaan se tuotti kukkivia 
versoja tasaisesti kaikkien käsittelyiden jälkeen. Pohjoisella genotyypillä havaittiin vernalisaatiovaatimus, koska se muodosti kukintoja ainoastaan vähintään 12 viikon vernalisaation koettuaan.

a)

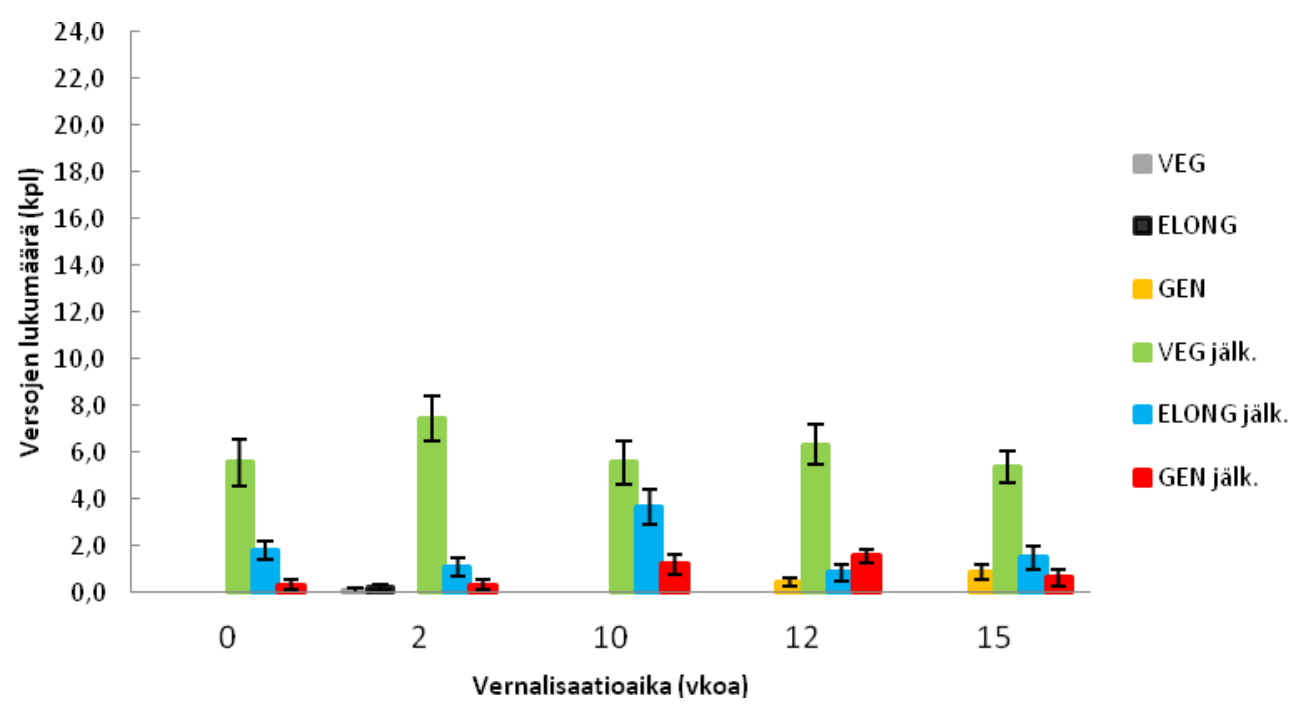

b)

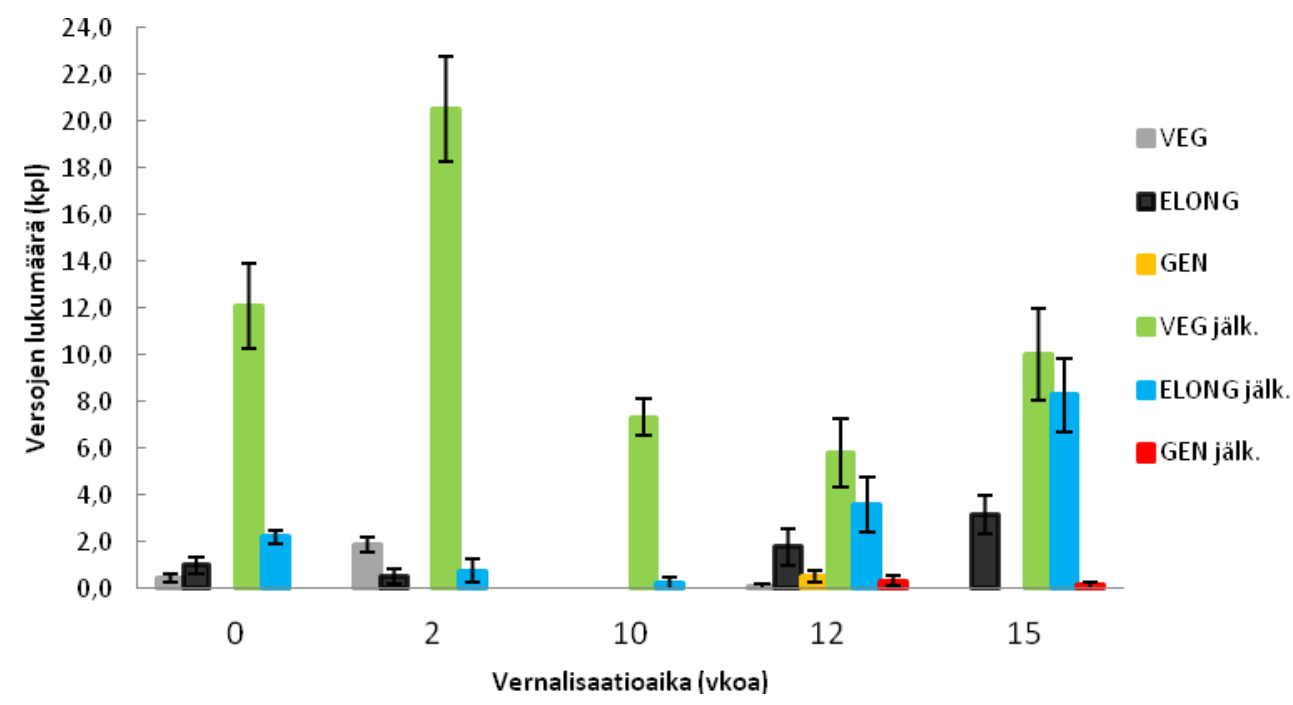

Kuva 2. Vernalisaatiokäsittelyn aikana ja jälkeen (jälk.) muodostuneiden vegetatiivisten (VEG), elongoituvien (ELONG) ja generatiivisten (GEN) versojen lukumäärä a) eteläistä ja b) pohjoista alkuperää olevissa timoteigenotyypeissä. $n=9 \pm$ SE.

Lyhyessä (12 h) päivän pituudessa ei muodostunut ollenkaan kukkivia tai elongoituvia versoja yhteenkään ei-vernalisoiduista tai vernalisoiduista kasveista. $\mathrm{GA}_{3}$-käsittely ei pystynyt korvaamaan pitkän päivän tarvetta kukkivien tai elongoituvien versojen muodostumiselle lyhyessä päivän pituudessa samankaltaisesti kuin esimerkiksi englanninraiheinällä (MacMillan ym. 2005). GA - käsitellyt kasvit 
olivat kuitenkin kontrollikasveja pidempiä (kuva 3), joka viittaa gibberelliinihapon verson pituuskasvua edistävään vaikutukseen.

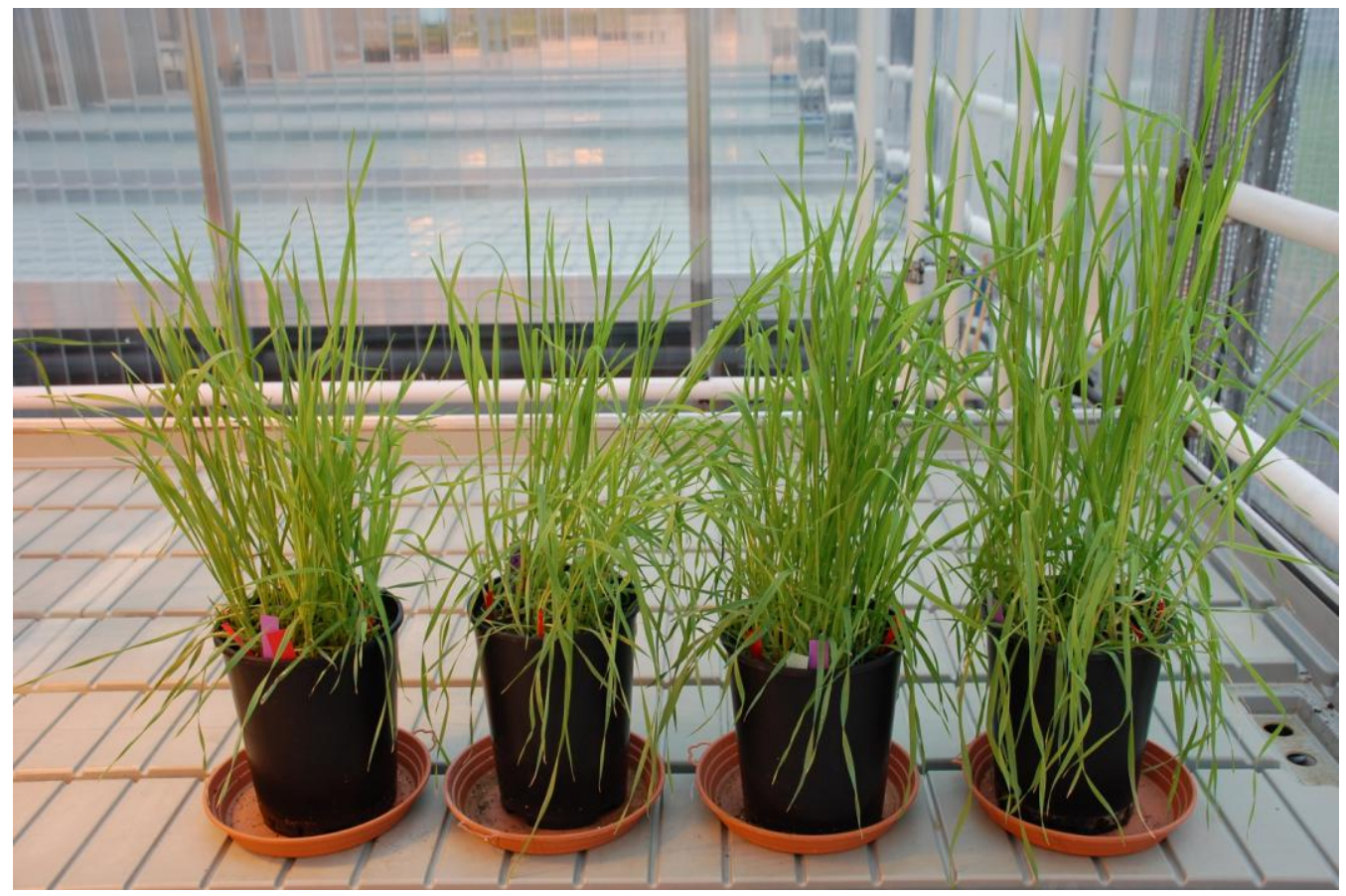

Kuva 3. Vasemmalta: 10 viikkoa vernalisoitu 'Iki', 10 viikkoa vern. $+\mathrm{GA}_{3}$ 'Iki', 10 viikkoa vern 'Tuure', 10 viikkoa vern.+ $\mathrm{GA}_{3}$ 'Tuure'. Kasvit vernalisoitiin 10 viikon ajan ja käsiteltiin $\mathrm{GA}_{3}$ :lla tai kontrollikäsittelyllä ja niiden kasvua seurattiin 8 viikon ajan 16 tunnin päivänpituudessa.

\section{Johtopäätökset}

Timotein kukinnan säätely vaikuttaa olevan erilainen verrattaessa muihin jo aiemmin tutkittuihin nurmikasveihin. Vernalisaatiolla on positiivinen vaikutus timotein kukintaan sen nopeuttaessa ja lisätessä kukintojen määrää verrattaessa vernalisoimattomiin kasveihin, kun taas elongoituvien versojen määrä vähenee vernalisoiduissa kasveissa. Gibberelliinihappokäsittely ei toimi samankaltaisesti timoteilla kuin esimerkiksi englanninraiheinällä (Lolium perenne L.), jolla se voi korvata pitkän päivän vaatimuksen ja sallia kukkimisen lyhyen päivän olosuhteissa. Lyhyt päivän pituus on vahva kukinnan estäjä timoteilla ja se vaatii tarpeeksi pitkän päivän kukkiakseen ja muodostaakseen elongoituvia versoja. Tulevaisuudessa syksyjen pidentyessä voidaan näitä tuloksia hyödyntää nurmikasvien jalostuksessa esimerkiksi käyttämällä tietoa geeneistä ja geenimuodoista, jotka ovat osallisena timotein kasvurytmin määräytymisessä. Versonmuodostuksen taustalla olevien geenien tunteminen nopeuttaa jalostuksen etenemistä timoteilla.

\section{Kirjallisuus}

Fiil, A., Jensen, B. L., Fjellheim, S., Lubberstedt, T., Andersen, J. R. 2011. Variation in the Vernalization Response of a Geographically Diverse Collection of Timohty Genotypes. Crop Science. vol 51, 6: 2689-2697.

Heide, O.M. 1994. Control of flowering and temperature in temperate grasses. New Phytologist. 128 :347-362. 
Isolahti, M. 2010. Timotein maantieteelliset geenipoolit ja niiden käyttö jalostusohjelmissa. Teoksessa: Maataloustieteen Päivät 2010. Suomen Maataloustieteellisen Seuran julkaisuja numero 26. Toimittanut Anneli Hopponen.http://www.smts.fi/jul2010/esite2010/049.pdf. Viitattu 17.11.2011.

Li, C. X., Distelfeld, A., Comis, A., Dubcovsky, J. 2011. Wheat flowering repressor VRN2 and promoter CO2 compete for interactions with NUCLEAR FACTOR-Y complexes. Plant Journal. vol 67, 5:763-773.

MacMillan, C. P., Blundell, C. A., King, R. W. 2005. Flowering of the grass Lolium perenne. Effects of vernalization and long days on gibberellin biosynthesis and signaling. Plant Physiology. 138, 3: 1794-1806.

Seppänen, M., Pakarinen, K., Jokela, V., Andersen, J.R., Fiil, A., Santanen, A., Virkajärvi, P. 2010.

Vernalization response of Phleum pratense and its relationships to stem lignification and floral transition. Annals of Botany. Annals of Botany 106 (5): 697-707.

Srikanth, A. \& Schmid. M. Regulation of flowering time: all roads lead to Rome. Cell. Mol. Life Sci. 68:2013-2037.

Sweet, N., Wiltshire, J.J.J. \& Baker, C. K. 1991. A new descriptive scale for early reproductive development in Lolium perenne L. Grass Forage Science 46: 201-206.

Virkajärvi, P., Pakarinen, K., Hyrkäs, M., Seppänen, M., Bélanger, Gilles. 2011. Tiller Characteristics of timothy and Tall fescue in Relation to Herbage Mass Accumulation. Crop Science. In Press. 